This is the author's final, peer-reviewed manuscript as accepted for publication. The publisher-formatted version may be available through the publisher's web site or your institution's library.

\title{
Expansion of human mesenchymal stem cells in a fixed-bed bioreactor system based on non-porous glass carrier - Part A: Inoculation, cultivation, and cell harvest procedures
}

Christian Weber, Denise Freimark, Ralf Pörtner, Pablo Pino-Grace, Sebastian Pohl, Christine Wallrapp, Peter Geigle, Peter Czermak

\section{How to cite this manuscript (APA format)}

If you make reference to this version of the manuscript, use the following citation format:

Weber, C., Freimark, D., Pörtner, R., Pino-Grace, P., Pohl, S., Wallrapp, C., Geigle, P., Czermak, P. (2010). Expansion of human mesenchymal stem cells in a fixed-bed bioreactor system based on non-porous glass carrier - Part A: Inoculation, cultivation, and cell harvest procedures. Retrieved from http://krex.ksu.edu

\section{Published Version Information}

Citation: Weber, C., Freimark, D., Pörtner, R., Pino-Grace, P., Pohl, S., Wallrapp, C., Geigle, P., Czermak, P. (2010). Expansion of human mesenchymal stem cells in a fixed-bed bioreactor system based on non-porous glass carrier - Part A: Inoculation, cultivation, and cell harvest procedures. International Journal of Artificial Organs, 33 (8), 512-525.

Copyright: The International Journal of Artificial Organs is published and copyrighted by Wichtig Editore - Milano (Italy)

Digital Object Identifier (DOI):

This item was retrieved from the K-State Research Exchange (K-REx), the institutional repository of Kansas State University. K-REx is available at http://krex.ksu.edu 
Expansion of human mesenchymal stem cells in a fixed-bed bioreactor system based on non-porous glass carrier - Part A: Inoculation, cultivation, and cell harvest procedures

Short title: Expansion of hMSC in a fixed-bed bioreactor - Part A

Christian Weber

Institute of Biopharmaceutical Technology, University of Applied Sciences GiessenFriedberg, Giessen, Germany

Denise Freimark

Institute of Biopharmaceutical Technology, University of Applied Sciences GiessenFriedberg, Giessen, Germany

Ralf Pörtner

Institute of bioprocess and Biosystems Engineering, University of Technology, Hamburg, Germany

Pablo Pino-Grace

Institute of Biopharmaceutical Technology, University of Applied Sciences GiessenFriedberg, Giessen, Germany

Sebastian Pohl Institute of Biopharmaceutical Technology, University of Applied Sciences GiessenFriedberg, Giessen, Germany 
Christine Wallrapp

CellMed AG, Alzenau, Germany

Peter Geigle

CellMed AG, Alzenau, Germany

Peter Czermak

Institute of Biopharmaceutical Technology, University of Applied Sciences Giessen-

Friedberg, Giessen, Germany

Department of Chemical Engineering, Kansas State University, Manhattan KS, USA

\section{Corresponding author}

Peter Czermak; Wiesenstraße 14, 35390 Giessen, Germany, phone +496413092634, fax +496413092553, e-mail peter.czermak@tg.fh-giessen.de 
The Authors state that this manuscript has not been published previously and is not currently being assessed for publication by any journal other than the International Journal of Artificial Organs.

Each Author has contributed substantially to the research, preparation and production of the paper and approves of its submission to the Journal. 


\section{Abstract}

Human mesenchymal stem cells (hMSC) are a promising cell source for several applications of regenerative medicine. The used cells are either autologous or allogenic, whereas the latter enables, especially by using of stem cell lines, a production of cell therapeutic or tissue engineered implants in stock. Therefore, the usually small initial cell number has to be increased. For that purpose bioreactors are demanded, which offer the controlled expansion of the hMSC under GMP-conform conditions.

In this study, divided in part $A$ and $B$, a fixed bed bioreactor system based on non-porous borosilicate glass spheres for the expansion of hMSC, demonstrated with the model cell line hMSC-TERT, is introduced. The system offers a comfortable automation of the inoculation, cultivation, and harvesting procedures. Furthermore the bioreactor owns a simple design which benefits the manufacturing as disposable. Part $A$ is focused on the inoculation, cultivation, and harvesting procedures. Cultivations were performed in lab scales up to a bed volume of $300 \mathrm{~cm}^{3}$. It could be shown that the fixed bed system, based on 2-mm borosilicate glass spheres, as well as the inoculation, cultivation, and harvesting procedures are suitable for the expansion of hMSC with high yield and vitality.

\section{Key words}

mesenchymal stem cells, hMSC-TERT, fixed-bed reactor, glass carrier 


\section{Introduction}

Due to their multipotency, mesenchymal stem cells can differentiate into various cell types like chondrocytes, neurocytes, myocytes, or osteocytes $[1,2]$ and are thus in focus of medicines and researchers. Autologous as well as allogenic cells can be used for regenerative medicine, whereas the allogenic cells have to be encapsulated to protect them from the host's immune system. However, the use of allogenic stem cells, especially stem cell lines, allows the production in shelf of cell therapeutic implants.

The expansion of mesenchymal stem cells from the initial cell number to an industrial relevant scale demands a bioreactor system that provides a gentle cultivation and harvest of the shear sensitive cells. Furthermore, the reactor system should be designed as a simple device that can be manufactured as disposable. The thereby saved cleaning and sterilization steps benefit the implementation of the system in GMP-conform processes. Additional important points concern the online monitoring of the cultivation status and the possibility of process automation.

A variety of bioreactor systems for the cultivation of diverse stem cell types have been described. It can be distinguished between static culture, often performed in cell culture plates or T-flasks [3-6], suspension reactors like spinner flasks [4, 7-9], stirred tanks or rotary bioreactors [6, 10-12], and perfusion reactors [4, 13-16]. Suspension and perfusion reactors require carrier or matrix systems which offer a suitable growth surface for the anchorage dependent cells. Cultivations of mesenchymal stem cells were performed, beside of T-flasks, in spinner flasks containing microcarrier $\left(\right.$ Cytodex $^{\circledR} 1$ and 3) [8], in rotary bioreactors [11], and in special reactors for stimulating the chondrogenic and osteogenic differentiation of encapsulated cells [4, 17]. The disadvantage by using static culture systems is the large labor input due to 
the intricate automation of the inoculation, cultivation, and harvesting procedures. A better automation is feasible in suspension reactors, but the harvesting procedure and especially the separation process of the cells from the carrier is still intricate and means additional devices. This drawback can be overcome by using of fixed-bed reactors based on non-porous carrier. The non-porosity supports the separation of enzymatically detached cells from the immobilized carrier by flushing them out with the medium flow. Fixed-bed reactors can be simple designed, that benefits the production as disposable. Additionally an automation and process monitoring can easily be realized.

Up to now no cultivation of hMSC in fixed-bed reactors in order to expand the initial cell number has been described. In this work an axial fixed-bed reactor system for the cultivation of hMSC, which considers the requirements stated above, is introduced. The fixed-bed is based on non-porous borosilicate glass spheres with a diameter of $2 \mathrm{~mm}$. These carriers are most suitable in respect to the nutrient supply and harvesting procedure as shown previously [18].

The used cells are human mesenchymal stem cells (hMSC), which are genetically modified with the gene of the catalytic subunit of human telomerase (TERT). This telomerase activity counteracts the shortening of the telomeres that occurs at each cleavage and thus leads to a permanent cell line [19].

Inoculation, cultivation, and harvesting procedures, which allow the automated generation of hMSC-TERT with high yield and vitality, were developed. Cultivations were performed in three different scales up to $300 \mathrm{~cm}^{3}$ and cell densities of up to $2.9 \times 10^{6} \mathrm{cells} / \mathrm{cm}^{3}$. The cultivation process was mathematically modeled in part B of this study. This enabled the theoretical scale up of the fixed-bed system which was exemplarily done for a target cell number of 20 billion. Cell dependent temporally 
oxygen profiles were used for monitoring of the cultivation status. Growth and consumption kinetics were determined by fitting model parameters to the experimental data and in order to validate the model, from separate experiments in 6well cell culture plates. 


\section{Materials and Methods}

All chemicals were obtained from Sigma-Aldrich (Deisenhofen, Germany) unless otherwise indicated.

The hMSC-TERT cell line was provided by the CellMed Ag (Alzenau, germany). The passage numbers throughout the experiments were between 65 and 85 .

All deviations resulted from repeated parallel experiments were expressed as standard deviation. Error propagations were considered using the Gaussian error propagation law. No further statistical evaluations were performed because of the small numbers of repeats of the cultivation runs.

The fixed-bed reactor system

The lab-scale fixed-bed reactors up to a bed volume $V_{F B}$ of $60 \mathrm{~cm}^{3}$ consisted of commercial glass syringes with special inserts, which replaced the original pistons (Figure $1 \mathrm{a}, \mathrm{b}$ ) [20]. This perforated funnel shaped inserts, made of PEEK, offered a hose connector and thus enabled the perfusion of the packed beds with a homogenous inflow. A second custom-made system used for the $300 \mathrm{~cm}^{3}$ scale was composed of a glass tube that was placed between stainless steel lid and bottom plates (Figure $1 \mathrm{c}$ ). These plates offered tube connections for the medium in- and outlet. A funnel shape insert for spreading of the incoming medium made up of stainless steel was placed in the inlet region. In both systems a stainless steel mesh avoided that the fixed bed enters the inlet tubing (Figure $1 \mathrm{a}$ ).

The fixed-bed reactors comprised non-porous borosilicate glass spheres with a diameter of $2 \mathrm{~mm}$. This means a volume specific growth surface $A_{F B} / V_{F B}$ of 18.3 $\mathrm{cm}^{2} / \mathrm{cm}^{3}$. A preliminary carrier screening with several porous and non-porous carriers 
has revealed, that non-porous borosilicate glass spheres of $2 \mathrm{~mm}$ diameter are most suitable in respect to growth, cell harvest, and nutrient supply [18].

Three flasks equipped with sterile air filters for pressure compensation were connected to the fixed-bed reactor and acted as conditioning, inoculum, waste, and collecting vessel (Figure $1 \mathrm{~d}$ ). The waste vessel contained the inoculum prior to the inoculation procedure. Oxygen concentration was measured in the medium in- and outflow using non-invasive oxygen sensors (Fibox 3, PreSens Precision Sensing $\mathrm{GmbH}$, Augsburg, Germany). Medium was perfused by means of a peristaltic pump (IPC-8, Ismatec SA, Glattbrugg, Switzerland) and directed using pinch valves (100P NC 24-05, msscientific GmbH, Berlin, Germany). The reactor system was operated in a humidified incubator at $37^{\circ} \mathrm{C}$ and $5 \% \mathrm{CO}_{2}$. The medium was aerated in the conditioning vessel by surface aeration.

\section{Static cell culture of hMSC-TERT}

\section{Cultivation in T-flasks}

Stocks were thawed in a $37^{\circ} \mathrm{C}$ water bath until ice crystals completely disappeared. Afterwards cell suspensions were diluted in culture medium, which consisted of Eagles Minimal Essential Medium (EMEM; Biochrom, Berlin, Germany), supplemented with $10 \%$ fetal calf serum (FCS; Biowest, Nuaillé, France), at room temperature and centrifuged at $230 \times \mathrm{g}$. After decantation of the supernatants, cells were resuspended in fresh medium, seeded into T300-flasks at a cell density of 5000 cells $/ \mathrm{cm}^{2}$, and cultured with $75 \mathrm{ml}$ medium in a humidified incubator at $37^{\circ} \mathrm{C}$ and $5 \%$ $\mathrm{CO}_{2}$ until a cell density of approximately 150,000 cells $/ \mathrm{cm}^{2}$ was reached. Medium was exchanged after three days of cultivation. Harvesting of cells was carried out by adding $0.05 \mathrm{ml} / \mathrm{cm}^{2}$ trypsin-EDTA solution, incubation for $5 \mathrm{~min}$, and rinsing of the 
flasks with medium to stop the enzymatic reaction. Cells were used for experiments or subcultivated in T300-flasks after centrifugation and resuspension in medium.

Determination of growth and glucose consumption kinetics in 6-well cell culture plates

A Monod kinetic limitation by glucose was assumed. For determination of the dependency of the growth rate and glucose consumption rate on the glucose concentration four 6-well cell culture plates were inoculated with $5000 \mathrm{cell} / \mathrm{cm}^{2}$ and cultured with $1 \mathrm{ml}$ medium per well for eight days. Three wells were harvested daily and the cell numbers as well as the glucose concentrations were determined. The growth rate at each time interval

$$
\Delta t^{j}=\left(t^{j}-t^{j-1}\right) \quad \mathrm{j}=1,2,3 \ldots \mathrm{n}
$$

was calculated by:

$$
\mu^{\Delta t^{j}}=\frac{\ln \left(X_{A}^{j}\right)-\ln \left(X_{A}^{j-1}\right)}{t^{j}-t^{j-1}} \quad \text { Equation } 1
$$

This equation is only valid for the log phase of the cell growth, which was determined by taking the logarithm of the growth curve.

The glucose consumption was related to the logarithmic mean of the cell density $X_{A, m}^{\Delta t^{j}}$ in order to obtain the cell specific glucose consumption rate: 
$q_{G l c}^{\Delta t^{j}}=\frac{\left(c_{G l c}^{j-1}-c_{G l c}^{j}\right) \cdot V_{C V}}{\left(t^{j}-t^{j-1}\right) \cdot X_{A, m}^{\Delta t^{j}} \cdot A}$

Equation 2

with the surface $A$, the glucose concentration $C_{G l c}$, and the medium volume $V$. The growth and consumption rates were plotted versus the logarithmic mean of the glucose concentration $c_{G l, m}^{\Delta t^{j}}$ so as to obtain the Monod kinetics for the growth rate

$$
\mu=\mu_{\max } \cdot \frac{c_{G l c}}{c_{G l c}+K_{M, \mu}}
$$

and the glucose consumption rate

$$
q_{G l c}=q_{G l c, \max } \cdot \frac{c_{G l c}}{c_{G l c}+K_{M, q_{G l c}}} \quad \text { Equation } 4
$$

by curve fitting.

\section{Dynamic cell culture of hMSC-TERT in the fixed bed systems}

Inoculation procedure

The inoculation procedure was performed in different ways. In the first method a $14.2 \mathrm{~cm}^{3}$ fixed bed was filled with cell suspension $\left(10,000\right.$ cells per $\mathrm{cm}^{2}$ growth surface area) and incubated for 90 min without perfusion. This method was then modified in order to return settled non-adhered cells into the fixed bed and thus increase the yield of adherent cells. For it the fixed bed was perfused for $7 \mathrm{~min}$ at a superficial velocity $v$ of $1.2 \times 10^{-4} \mathrm{~m} \mathrm{~s}^{-1}$ after time intervals of $30 \mathrm{~min}$. This cycle was 
repeated two or four times, so that the overall durations of these inoculation procedures were 104 and $178 \mathrm{~min}$. The perfusion time was calculated from the fixed bed height $h_{F B}$, the superficial velocity $v$, and the factor 1.1, which means an overlap of the cell suspension over the fixed bed of $10 \%$ :

$$
t_{\text {perf }}=1.1 \cdot \frac{h_{F B}}{v}
$$

Equation 5

During the 30-min phases without perfusion the valve V1 (Figure $1 \mathrm{c}$ ) was closed to avoid a sedimentation of cells into the tubing. After the inoculation procedure, the fixed bed was rinsed with medium so as to get rid of non-adherent cells. The fixed beds were removed in layers to represent the axial cell density distribution. For determination of the cell number, nuclei were counted using a Neubauer hematocytometer after lysis of the cells with citric acid and staining with crystal violet as previously described [21]. The experiments were performed in triplicates.

\section{Influence of the superficial velocity on the growth rate}

Due to the non-porosity of the carrier, the cells are totally exposed to shear stress caused by the medium flow. This demands a determination of an upper limit for the superficial velocity $v$, which is important for an up-scaling of the process (see part B of this publication). The used criterion is the point at which the mean growth rate $\mu_{m}$ starts to decrease.

The investigations were carried out in four parallel-operated $14.2 \mathrm{~cm}^{3}$ fixed-bed reactors. For that, fixed beds were inoculated as described above with $1.83 \times 10^{5}$ 
cells $/ \mathrm{cm}^{3}\left(10^{4}\right.$ cells $\left./ \mathrm{cm}^{2}\right)$ and cultivated at three different superficial velocities $v$. For more details of these cultivations see Table 1. After cultivation, the fixed beds were removed in layers to represent the axial cell density distribution. Cell densities were determined by crystal violet staining of the nuclei at the end of the cultivations [21]. The mean growth rates were calculated according to Equation 1.

\section{Cultivation in different fixed bed scales}

Additional to the cultivation in $14.2 \mathrm{~cm}^{3}$ fixed-bed reactors as described above, cultivations in a $60 \mathrm{~cm}^{3}$ and $300 \mathrm{~cm}^{3}$ scale were performed. The reactors were inoculated with $1.3 \times 10^{5}$ cells $/ \mathrm{cm}^{3}\left(7 \times 10^{3}\right.$ cells $\left./ \mathrm{cm}^{2}\right)$ and $1.8 \times 10^{5} \mathrm{cells} / \mathrm{cm}^{3}(10 \times$ $10^{3}$ cells $/ \mathrm{cm}^{2}$ ), respectively, but it has to be noted, that this was not the initial cell density since only $50 \%$ of the inoculated cells got attached to the carrier as it will be shown subsequently. More details to the cultivations are given in Table 1. Cell densities were calculated from the oxygen consumption and determined by counting of the nuclei after cell lysis and crystal violet staining.

The cell numbers $N_{X}^{j}$ at the time points $t^{j}$ were calculated using the oxygen concentration difference between the in- and outlet $c_{O x, \text { in }}^{j}-c_{O x, \text { out }}^{j}$, the oxygen consumption rate $q_{O x}$ as well as the volume flow rate $\dot{V}$ :

$$
N_{X}^{j}=\frac{\left(c_{O x, \text { in }}^{j}-c_{O X, \text { out }}^{j}\right) \cdot \dot{V}}{q_{O x}} \quad \text { Equation } 6
$$


For simplification, the oxygen uptake kinetic was considered as independent from the concentration and calculated with the oxygen difference between the medium in- and outlet at the end of the fixed bed cultivation:

$q_{O x}=\frac{\left(c_{O x, C V}^{n}-s_{O x, F B}^{n}\right) \cdot \dot{V}}{N_{X}^{n}}$

Equation 7

$N_{X}^{n}$ is the cell number counted at the end of cultivation, $c_{O X, C V}^{n}$ is the associated oxygen concentrations in the conditioning vessel and thus in the inlet of the fixed bed and $c_{O X, F B}^{n}$ the outlet concentration.

From the cell densities $X_{F B}^{j}$, calculated with the cell number $N_{X}^{j}$ and the fixedbed volume $V_{F B}$, the initial cell density $X_{F B}^{0}$ and the mean growth rate $\mu_{m}$ were obtained by curve fitting:

$$
\begin{array}{ll}
X_{F B} & =X_{F B}^{0} \cdot e^{\mu_{m} \cdot t} \quad \text { Equation } 8
\end{array}
$$

The mean glucose consumption rate $q_{G l c, m}$ was calculated by the following equation

$$
q_{G l c, m}=\frac{\left(c_{G l c}^{0}-c_{G l c}^{n}\right) \cdot V_{C V}}{X_{F B, m} \cdot V_{F B} \cdot t^{n}}
$$

Equation 9

with the medium volume in the conditioning vessel $V_{C V}$, the cultivation duration $t^{n}$, and the log mean of the cell density 


$$
X_{F B, m}=\frac{X_{F B}^{n}-X_{F B}^{0}}{\ln \left(\frac{X_{F B}^{n}}{X_{F B}^{0}}\right)}
$$

\section{Harvesting procedure}

Investigations for the cell harvesting were performed in $14.2 \mathrm{~cm}^{3}$ fixed-bed reactors at a cell density $X_{A}$ of about $10^{5}$ cells $/ \mathrm{cm}^{2}$. Accutase ${ }^{\mathrm{TM}}$ was mainly chosen because it is less harmful to the cells compared to trypsin. The investigated methods can be divided in two classes:

1. The enzyme solution and with it the detached cells were cyclic perfused with a comparably high superficial velocity $v$.

2. The enzyme solution was perfused at lower velocity and directly led to the collecting vessel. Then the detached cells were flushed out by means of perfusion of the fixed bed with medium at higher velocity, which was directed to the collecting vessel too.

The second procedure is assumed to be more gently because of the avoided recirculation of detached cells which causes less shear stress. More details to the harvesting experiments are given in Table 2. In order to avoid inhibiting effects of the serum to the enzyme activity the fixed beds were rinsed with $100 \mathrm{ml}$ PBS in each case prior to enzymatic treatment.

Evaluation criteria for the harvesting procedures were the yield, which is defined as the number of detached cells to the overall cell number in the fixed bed, and the vitality, that is defined as the ratio of living cells to the total number of detached cells. Vitality was measured with the trypan blue exclusion method. 


\section{Results and Discussion}

Growth and glucose uptake kinetics in 6-well cell culture plates

The glucose dependent growth and glucose consumption kinetics in static culture were obtained by fitting of Equation 3 and Equation 4 to the growth or consumption rate versus glucose concentration curves (Figure 2 and Figure 3). The maximal growth rate $\mu_{\max }$ and the Monod constant $K_{M, \mu_{G l c}}$ were found to be $0.66 \pm 0.02 \mathrm{~d}^{-1}$ and $0.14 \pm 0.03 \mathrm{mg} \mathrm{ml}^{-1}$. The maximal glucose uptake rate $q_{G l c \text {,max }}$ was $(7.7 \pm 1.1) \times 10^{-8} \mathrm{mg} \mathrm{h}^{-1}$ cell $^{-1}$ with the according Monod constant $K_{M, q_{G l c}}=$ $0.16 \pm 0.06 \mathrm{mg} \mathrm{ml}^{-1}$

It was assumed, that glucose is the limiting medium component. This assumption is corroborated by the fact, that the curve in Figure 3 passes the origin of the coordinates. A limitation by other nutrients like glutamine would shift the intersection with the x-coordinate. In addition, glutamine has been reported to be an unimportant energy source for human, goat, and rat mesenchymal stem cells [22].

The relation of lactate to consumed glucose is $2.74 \mathrm{~mol} / \mathrm{mol}$. This points at an inefficient metabolism of glucose for energy mainly via glycolysis. As well Schop et al. (2009) reported a high lactate/glucose ratio of up to $2.13 \mathrm{~mol} / \mathrm{mol}$ at the cultivation of hMSC [22].

An oxygen limitation during the cultivation in cell culture plates can be excluded because of the high surface area to cell number relation. An estimation of the oxygen saturation of the medium at the highest cell density of $6.3 \times 10^{4}$ cells $\mathrm{cm}^{-2}$ using an oxygen transfer coefficient of $0.184 \mathrm{~m} \mathrm{~h}^{-1}$ [23] and an oxygen consumption rate of $2 \mathrm{x}$ $10^{-8} \mathrm{mg} \mathrm{h}^{-1}$ cell $^{-1}$ leads to an saturation of about $99 \%$. Assuming a higher oxygen 
consumption rate of $4 \times 10^{-8} \mathrm{mg} \mathrm{h}^{-1}$ cell $^{-1}$ would only reduce the oxygen saturation to about $97 \%$.

Table 3 and Table 4 give some examples of published growth and glucose consumption kinetics of several animal and human cells or cell lines. The kinetics determined in this work are in the same range of those reported values.

\section{Cultivation in fixed-bed reactors}

Inoculation procedure

The yield of adherent cells after the inoculation procedure could have been increased by repeated perfusion of the fixed bed from $35 \%$, without perfusion, to $49 \%$ (Figure 4). No tendency dependent on the inoculation strategy regarding to the axial cell distribution could be detected.

Additional perfusion steps, another superficial velocities $v$, or time intervals between the perfusion steps could lead to a further enhancement of the yield of adherent cells. Thus, continuative studies are recommended.

Influence of the superficial velocity on the growth rate

The mean growth rate $\mu_{m}$ in the exponential phase decreases from $0.62 \pm 0.01 \mathrm{~d}^{-1}$ at a superficial velocity $v$ of $2.65 \times 10^{-4} \mathrm{~m} \mathrm{~s}^{-1}$ to $0.29 \pm 0.01 \mathrm{~d}^{-1}$ at a superficial velocity of $1.59 \times 10^{-3} \mathrm{~m} \mathrm{~s}^{-1}$ (Figure 5). A flow velocity dependent trend in axial cell distribution could not be observed.

A mean growth rate $\mu_{m}$ of $0.62 \mathrm{~d}^{-1}$ is close to the maximal growth rate $\mu_{\max }$ of $0.66 \mathrm{~d}^{-1}$, determined in static culture in 6-well cell culture plates, which can only be reached by an infinite glucose concentration because of the Monod kinetic. Therefore it may be assumed, that a further decrease of superficial velocity $v$ would not lead to 
a significant increase in growth rate. For all of the subsequently performed cultivations, the rounded superficial velocity $v$ of $3.0 \times 10^{-4} \mathrm{~m} \mathrm{~s}^{-1}$ was used.

\section{Cultivation of hMSC-TERT at different fixed bed scales}

hMSC-TERT were cultured in scales $V_{F B}$ of 14,60 , and $300 \mathrm{~cm}^{3}$. Figure 6 to Figure 8 show the experimental data. The results are summarized in Table 5.

The cells were cultured up to a density $X_{F B}^{n}$ of $(2.93 \pm 0.11) \times 10^{6} \mathrm{cells} / \mathrm{cm}^{3}$. Higher cell densities are not recommendable because of the risk of channeling and drawbacks by up-scaling of the fixed bed system, as shown in part B of this publication. The initial cell densities $X_{F B}^{0}$ and $X_{A}^{0}$ were about 50 to $60 \%$ of the inoculated cell densities that confirms the results of the inoculation procedure.

The mean growth rate $\mu_{\mathrm{m}}$ and the oxygen consumption rate $q_{O x}$ decreased with advancing passage number from 0.60 to $0.42 \mathrm{~d}^{-1}$ and $2,03 \times 10^{-8}$ to $1,08 \times 10^{-8}$ $\mathrm{mg} \mathrm{h}^{-1}$ cell $^{-1}$, respectively, whereas the mean glucose consumption rate $q_{G l c, \mathrm{~m}}$ increased from $7,65 \times 10^{-8}$ to $9,50 \times 10^{-8} \mathrm{mg} \mathrm{h}^{-1}$ cell $^{-1}$. Although hMSC-TERT are considered as a permanent cell line, changes in growth and consumption kinetics occur within 17 passages. A decrease of growth rate with advancing passage number has been reported for other cells like hMSC or adipose stem cells (rhesus monkey) $[24,25]$. A consequence of this is that an optimized process design is only valid for a closed range of passage numbers.

All kinetics are within the range of those reported for several animal and human cells or cell lines (Table 3, Table 4, and Table 6).

For the oxygen uptake a zero order kinetic was assumed. This assumption is valid for an oxygen saturation above $20 \%$ and thus for the performed cultivation runs 
[26]. Furthermore in part $\mathrm{B}$ of this study the constants of the growth kinetic $\mu_{\max }$ and $K_{M, \mu_{G l c}}$ were determined by fitting model parameters to the experimental data of the fixed-bed cultivations [27]. Comparing the constants of the cultivation in the $14 \mathrm{~cm}^{3}$ scale (passage number $=68$ ) to those of the cultivation in 6 -well cell culture plates (passage number $=69$ ) of this publication no remarkable deviation in $K_{M, \mu_{G l c}}$ occurred. This suggests that the oxygen saturation has at least in the range of $35 \%$ to $100 \%$ a negligible effect on the growth kinetic. Otherwise the observable Monod constant $K_{M, \mu_{G l c}}$ for the glucose dependence of the growth rate would be wrongly increased.

\section{Harvesting procedure}

Increasing of the superficial velocity $v$ of the cyclic perfused Accutase $^{\mathrm{TM}}$ solution from $8.0 \times 10^{-4}$ to $3.2 \times 10^{-3} \mathrm{~m} \mathrm{~s}^{-1}$ and extension of the residence time from 10 to 20 min enhanced the yield from $5 \%$ to $76 \%$ (Figure 9, procedure a-c; Table 2). The vitality was $84 \%$. Better results were obtained with non-cyclic perfusion of the enzyme solution and flushing out of the cells by a short time perfusion of the fixed bed with a comparably high superficial velocity (Figure 9, procedure d-i; Table 2). Treatment of the cells with Accutase ${ }^{\mathrm{TM}}$ solution for $10 \mathrm{~min}$ and a superficial velocity $v$ of $1.8 \times 10^{-4} \mathrm{~m} \mathrm{~s}^{-1}$ followed by perfusion with medium for 2 min and a superficial velocity of $3.2 \times 10^{-3} \mathrm{~m} \mathrm{~s}^{-1}$ resulted in a yield of $(82.1 \pm 2.3) \%$ and a vitality of $(96.5 \pm$ 0.7)\%. Altogether, non-cyclic perfusion led to higher vitalities compared to cyclic perfusion, which is explainable by the reduced shear stress due to non-repeated passage of already detached cells through the system components. 


\section{Conclusion}

The introduced fixed-bed reactor concept based on non-porous borosilicate glass spheres is suitable for the cultivation of hMSC-TERT. An application of the system for the cultivation of non-modified hMSC is supposable.

The introduced inoculation, cultivation, and harvesting procedures are designed for an automated performance of hMSC-TERT expansion with high yield and vitality of the harvested cells.

The simple designed reactor, which includes in principle a carrier filled tube connected to a conditioning vessel, enables a production of this system as disposable. An easy automation and a comfortable process monitoring by measuring of the oxygen concentration at the inlet and outlet or glucose concentration in the conditioning vessel, for example, benefit the transfer of this system into a GMPprocess. 


\section{Acknowledgements}

The authors would like to thank the Federal ministry of Economics and Technology for financial support as well as the CellMed AG for providing the production cell line hMSC-TERT. 


\section{References}

[1] Barry, F.P. and J.M. Murphy. Mesenchymal stem cells: clinical applications and biological characterization. Int J Biochem Cell Biol. 2004; 36: 568-584

[2] Krampera, M., G. Pizzolo, G. Aprili and M. Franchini. Mesenchymal stem cells for bone, cartilage, tendon and skeletal muscle repair. Bone. 2006; 39: 678683

[3] Oh, S.K.W., W.J. Fong, Y. Teo, H.L. Tan, J. Padmanabhan, A.C.P. Chin and A.B.H. Choo. High density cultures of embryonic stem cells. Biotechnol Bioeng. 2005; 91: 523-533

[4] Meinel, L., V. Karageorgiou, R. Fajardo, B. Snyder, V. Shinde-Patil, L. Zichner, D. Kaplan, R. Langer and G. Vunjak-Novacovic. Bone tissue engineering using human mesenchymal stem cells: effects of scaffold material and medium flow. Ann Biomed Eng. 2004; 32: 112-122

[5] Thomas, R.J., A. Chandra, Y. Liu, P.C. Hourd, P.P. Conway and D.J. Williams. Manufacture of a human mesenchymal stem cell population using an automated cell culture platform. Cytotechnology. 2007; 55: 31-39

[6] Lin, H.J., T.J. O'Shaughnessy, J. Kelly and W. Ma. Neural stem cell differentiation in a cell- collagen- bioreactor culture system. Dev Brain Res. 2004; 153: 163-173

[7] Abranches, E., E. Bekman, D. Henrique and J.M.S. Cabral. Expansion of mouse embryonic stem cells on microcarriers. Biotechnol Bioeng. 2006; 96: 1211-1221

[8] Frauenschuh, S., E. Reichmann, Y. Ibold, P.M. Goetz, M. Sittinger and J. Ringe. A microcarrier-based cultivation system for expansion of primary mesenchymal stem cells. Biotechnol Prog. 2007; 23: 187-193

[9] Sen, A., M.S. Kallos and L.A. Behie. Effects of hydrodynamics on cultures of mammalian neural stem cell aggregates in suspension bioreactors. Ind Eng Chem Res. 2001 40: 5350-5357

[10] Gerecht-Nir, S., S. Cohen and J. Itskovitz-Eldor. Bioreactor cultivation enhances the efficiency of human embryoid body ( $h E B$ ) formation and differentiation. Biotechnol Bioeng. 2004; 86: 313-320 
[11] Chen, X., H. Xu, C. Wan, M. McCaigue and G. Lia. Bioreactor expansion of human adult bone marrow-derived mesenchymal stem cells (MSCs) . Stem Cells. 2006; 24: 2052-2059

[12] Serra, M., C. Brito, S.B. Leite, E. Gorjup, H. von Briesen, M.J.T. Carrondo and P.M. Alves. Stirred bioreactors for the expansion of adult pancreatic stem cells. Ann Anatomy. 2009; 191: 104-115

[13] Bauwens, C., T. Yin, S. Dang, R. Peerani and P.W. Zandstra. Development of a perfusion fed bioreactor for embryonic stem cell-derived cardiomyocyte generation: oxygen-mediated enhancement of cardiomyocyte output. Biotechnol Bioeng. 2004; 90: 452-461

[14] Cho, C.H., J.F. Eliason and H.W.T. Matthew. Application of porous glycosaminoglycan-based scaffolds for expansion of human cord blood stem cells in perfusion culture. J Biomed Mat Res Part A. 2007; 86A: 98-107

[15] Jelinek, N., S. Schmidt, S. Thoma, C. Wandrey and M. Biselli, Effects of collagenase on human hematopoietic cells Animal cell technology: products from cells, cells as products - proceedings of the 16th ESACT meeting. 2000, Lugano, Switzerland: Bernard A., Griffiths B., Noé W., Wurm, F.

[16] Meissner, P., B. Schröder, C. Herfurth and M. Biselli. Development of a fixed bed bioreactor for the expansion of human hematopoietic progenitor cells. Cytotechnology. 1999; 30: 227-234

[17] Mauney, J.R., S. Sjosto, J. Blumberg, R. Horan, J.P. O Novakovic, V. Volloch and V. Kaplan. Mechanical stimulation promotes osteogenic differentiation of human bone marrow stromal cells on 3-D partially demineralized bone scaffolds in vitro. Calcif Tissue Int. 2004; 74: 458-468

[18] Weber, C., S. Pohl, R. Poertner, P. Pino-Grace, D. Freimark, C. Wallrapp, P. Geigle and P. Czermak, Production process for stem cell-based therapeutic implants - Expansion of the production cell line and cultivation of encapsulated cells. Advances in Biochemical Engineering/Biotechnology, eds.: C. Kasper, M. van Griensven und R. Poertner, Vol. Bioreactor Systems for Tissue Engineering II - Strategies for stem cell expansion and differentiation. 2010, Berlin: Springer.

[19] Simonsen, J.L., C. Rosada, N. Serakinci, J. Justesen, K. Stenderup, S.I.S. Rattan, T.G. Jensen and M. Kassem. Telomerase expression extends the 
proliferative life-span and maintains the osteogenic potential of human bone marrow stromal cells. Nat Biotechnol. 2002; 20: 592-596

[20] Weber, C., S. Pohl, R. Pörtner, C. Wallrapp, M. Kassem, P. Geigle and P. Czermak. Cultivation and differentiation of encapsulated hMSC-TERT in a disposable small-scale syringe-like fixed bed reactor. Open Biomed Eng J. 2007; 1: 64-70

[21] Weber, C., S. Pohl, R. Pörtner, C. Wallrapp, M. Kassem, P. Geigle and P. Czermak. Expansion and harvesting of hMSC-TERT. Open Biomed Eng J. 2007; 1: 38-46

[22] Schop, D., F.W. Janssen, L.D.S. van Rijn, H. Fernandes, R.M. Bloem, J.D. de Bruijn and R. van Dijkhuizen-Radersma. Growth, metabolism, and growth inhibitors of mesenchymal stem cells. Tissue Eng A. 2009; 15: 1877-1886

[23] Zimmermann, H.F. Entwicklung der Hochdurchsatzfermentation: Bestimmung der bioverfahrenstechnischen Anforderungen und Implementierung der Laborautomation. Fakultät für Informatik und Elektrotechnik, University of Rostock; PhD Thesis, 2005

[24] Lonergan, T., C. Brenner and B. Bavister. Differentiation-related changes in mitochondrial properties as indicators of stem cell competence. J Cell Physiol. 2006; 208: 149-153

[25] Weber, C., S. Gokorsch and P. Czermak. Expansion and chondrogenic differentiation of human mesenchymal stem cells. Int J Artif Organs. 2007; 30: 611-618

[26] Eibl, D., R. Eibl, R. Pörtner, G. Catapano and P. Czermak, Cell and tissue reaction engineering. 2009, Berlin-Heidelberg: Springer-Verlag.

[27] Weber, C., D. Freimark, R. Poertner, P. Pino-Grace, S. Pohl, C. Wallrapp, P. Geigle and P. Czermak. Expansion of human mesenchymal stem cells in a fixed-bed bioreactors system - Part B: Modeling and scale up. Int J Artif Organs 2010;

[28] Higuera, G., D. Schop, F. Janssen, R. van Dijkhuizen-Radersma, T. van Boxtel and C.A. van Blitterswijk. Quantifying in vitro growth and metabolism kinetics of human mesenchymal stem cells using a mathematical model. Tissue Eng Part A. 2009; 15: 1-11 
[29] Conget, P. and J.J. Minguell. Phenotypical and functional properties of human bone marrow mesenchymal progenitor cells. J Cell Physiol. 1999; 181: 67-73

[30] Guo, Z., J. Yang, X. Liu, X. Li, C. Hou, P.H. Tang and N. Mao. Biological features of mesenchymal stem cells from human bone marrow. Chin Med J. 2001; 114: 950-953

[31] Liu, Y.-H., J.-X. Bi, A.-P. Zeng and J.-Q. Yuan. A simple kinetic model for myeloma cell culture with consideration of lysine limitation. Bioprocess Biosyst Eng. 2008; 31: 569-577

[32] Soukup, T., J. Mokrý, J. Karbanová, R. Pytlík, P. Suchomel and L. Kučerová. Mesenchymal stem cells isolated from human bone marrow: cultivation, phenotypic analysis and changes in proliferation kinetics. Acta Med. 2006; 49: 27-33

[33] Amit, M., M.K. Carpenter, M.S. Inokuma, C.P. Chiu and J.A. Thomson. Clonally derived human embryonic stem cell lines maintain pluripotency and proliferative potential for prolonged periods of pulture. Dev Biol. 2000; 227: 271- 278

[34] Breguet, V., R.I. Gugerli, U. von Stockar and I.W. Marison. CHO immobilization in alginate/poly-L-lysine microcapsules: an understanding of potential and limitations. Cytotechnology. 2007; 53: 81- 93

[35] Shirai, Y., K. Hashimoto and H. Takamatsu. Growth kinetics of Hybridoma cells in high density culture. J Ferment Bioeng. 1992; 73: 159-165

[36] Schop, D., F.W. Janssen, E. Borgart, J.D. de Bruijn and R. van DijkhuizenRadersma. Expansion of mesenchymal stem cells using a microcarrier-based cultivation system: growth and metabolism. J Tissue Eng Regen Med. 2008; 2: 126-135

[37] Boren, J., M. Cascante, S. Marin, B. Comın-Anduix, J.J. Centelles, S. Lim, S. Bassilian, S. Ahmed, W.N.P. Lee and L.G. Boros. Gleevec (STI571) influences metabolic enzyme activities and glucose carbon flow toward nucleic acid and fatty acid synthesis in myeloid tumor cells. J Biol Chem. 2001; 276: 37747- 37753

[38] Lubiniecki, A.S., Large-scale mammalian cell culture technology. Vol. 10. 1990: Marcel Dekker Inc. 
[39] Peng, C.A. and B.A. Palson. Determination of specific oxygen uptake rates in human hematopoietic cultures and implications for bioreactor design. Ann Biomed Eng. 1996; 24: 373-381

[40] Acevedo, C.A., C. Weinstein-Oppenheimer, D.I. Brown, H. Huebner, R. Buchholz and M.E. Young. A mathematical model for the design of fibrin microcapsules with skin cells. Bioprocess Biosyst Eng. 2008; 32: 341-351

[41] De Leon, A., H. Mayani and O.T. Ramırez. Design, characterization and application of a minibioreactor for the culture of human hematopoietic cells under controlled conditions. Cytotechnology. 1998; 28: 127-138

[42] Youn, B.S., A. Sen and L.A. Behie. Scale-up of breast cancer stem cell aggregate cultures to suspension bioreactors. Biotechnol Prog. 2006; 22: 801810

[43] Shirai, Y., K. Hashimoto, H. Yamaji and H. Kawahara. Oxygen uptake rate of immobilized growing hybridoma cells. Appl Microbiol Biotechnol. 1988; 29: 113-118 


\section{Nomenclature}

A growth surface $\left[\mathrm{m}^{2}\right]$

$A_{F B} \quad$ overall growth surface of the fixed bed $\left[\mathrm{m}^{2}\right]$

$c_{\text {Glc }} \quad$ glucose concentration $\left[\mathrm{kg} \mathrm{m}^{-3}\right]$

$c_{G l c}^{0} \quad$ initial glucose concentration $\left[\mathrm{kg} \mathrm{m}^{-3}\right]$

$c_{G l c}^{n} \quad$ glucose concentration at the end of the cultivation (time point $t^{n}$ ) [kg m$\left.{ }^{3}\right]$

$c_{G l c, C V}$ glucose concentration in the conditioning vessel $\left[\mathrm{kg} \mathrm{m}^{-3}\right]$

$c_{G l c, m}^{\Delta t^{j}}$ logarithmic mean of the glucose concentration in the time interval $\Delta t^{j}\left[\mathrm{~kg} \mathrm{~m}^{-3}\right]$

$C_{\mathrm{Lac}, C V}$ lactate concentration in the conditioning vessel $\left[\mathrm{kg} \mathrm{m}^{-3}\right]$

$c_{O x}^{*} \quad$ maximal dissolved oxygen $\left[\mathrm{kg} \mathrm{m}^{-3}\right]$

$c_{O x, C V}$ oxygen concentration in the conditioning vessel (fixed-bed inlet) [\%]

$c_{O x, F B}$ oxygen concentration in the fixed-bed outlet [\%]

$h_{F B} \quad$ fixed bed height [m]

$K_{M, \mu}$ Monod constant for the growth kinetic $\left[\mathrm{kg} \mathrm{m}^{-3}\right]$

$K_{M, q_{G l c}}$ Monod constant for the glucose consumption kinetic $\left[\mathrm{kg} \mathrm{m}^{-3}\right]$

$N_{X} \quad$ cell number [-] 
$N_{X}^{j} \quad$ cell number at the time point $t^{j}[-]$

$N_{X}^{n} \quad$ cell number at the end of cultivation (time point $t^{n}$ ) [-]

$q_{\text {Glc }} \quad$ glucose consumption rate $\left[\mathrm{kg} \mathrm{s}^{-1}\right.$ cell $\left.^{-1}\right]$

$q_{G l c}^{\Delta t^{j}} \quad$ glucose consumption rate in the time interval $\Delta t^{j}\left[\mathrm{~kg} \mathrm{~s}^{-1} \mathrm{cell}^{-1}\right]$

$q_{G l c, \mathrm{~m}}$ mean glucose consumption rate $\left[\mathrm{kg} \mathrm{s}^{-1}\right.$ cell $\left.^{-1}\right]$

$q_{\text {Glc,max }}$ maximal glucose consumption rate $\left[\mathrm{kg} \mathrm{s}^{-1} \mathrm{cell}^{-1}\right]$

$q_{O x} \quad$ oxygen consumption rate $\left[\mathrm{kg} \mathrm{s}^{-1}\right.$ cell $\left.^{-1}\right]$

$s_{O x, C V}$ oxygen saturation in the conditioning vessel (fixed-bed inlet) [\%]

$s_{O x, F B}$ oxygen saturation in the fixed-bed outlet [\%]

$t_{\text {perf }} \quad$ time of perfusion [s]

$v \quad$ superficial velocity $\left[\mathrm{m} \mathrm{s}^{-1}\right]$

$V \quad$ volume $\left[\mathrm{m}^{3}\right]$

$\dot{V} \quad$ flow rate $\left[\mathrm{m}^{3} \mathrm{~s}^{-1}\right]$

$V_{F B} \quad$ fixed bed volume $\left[\mathrm{m}^{3}\right]$

$V_{C V} \quad$ medium volume (conditioning vessel) $\left[\mathrm{m}^{3}\right]$

$X_{A} \quad$ area related cell density $\left[\mathrm{m}^{-2}\right]$ 
$X_{A, m}^{\Delta t^{j}}$ logarithmic mean of the area related cell density in the time interval $\Delta t^{j}\left[\mathrm{~m}^{-2}\right]$

$X_{F B} \quad$ volume related cell density $\left[\mathrm{m}^{-3}\right]$

$X_{F B}^{n} \quad$ cell density at the end of cultivation $\left[\mathrm{m}^{-3}\right]$

$X_{F B, m}^{\Delta t^{j}}$ logarithmic mean of the volume related cell density in the time interval $\Delta t^{j}$ $\left[\mathrm{m}^{-3}\right]$

$\Delta t^{j} \quad$ time interval $t^{j}-t^{j-1} \quad \mathrm{j}=1,2,3 \ldots \mathrm{n}$

$\mu \quad$ growth rate $\left[\mathrm{s}^{-1}\right]$

$\mu_{\mathrm{m}} \quad$ mean growth rate $\left[\mathrm{s}^{-1}\right]$

$\mu_{\max } \quad$ maximal growth rate $\left[\mathrm{s}^{-1}\right]$

$\mu^{\Delta t^{j}} \quad$ growth rate in the time interval $\Delta t^{j}\left[\mathrm{~s}^{-1}\right]$ 


\section{Legends}

Figure 1: Fixed bed bioreactor systems for the expansion of hMSC-TERT.

a) Custom made insert for enabling the usage of commercial available syringes as fixed bed bioreactors

b) Syringe based small-scale fixed-bed reactor filled with $2 \mathrm{~mm}$ borosilicate glass spheres

c) Fixed bed bioreactor in a up to $500-\mathrm{cm}^{3}$ scale filled with 2-mm borosilicate glass spheres

d) Scheme of the bioreactor periphery

Figure 2: Monod kinetic of the growth rate (medium volume per well $=1.0 \mathrm{ml}$ ). The data represents the mean \pm standard deviation (SD) of triplicates.

Figure 3: Monod kinetic of the glucose consumption rate (medium volume per well = $1.0 \mathrm{ml}$ ). The data represents the mean \pm standard deviation (SD) of triplicates.

Figure 4: Yield of adherent cells and axial cell density distribution obtained by application of different inoculation procedures. Perfusion steps with a superficial velocity $v$ of $1.2 \times 10^{-4} \mathrm{~m} \mathrm{~s}^{-1}$ were applied for $7 \mathrm{~min}$ in time intervals of $30 \mathrm{~min}$. The data represents the mean \pm standard deviation of triplicates. 
Figure 5: Axial cell density distributions and mean growth rates $\mu_{m}$ after six days of cultivation of hMSC-TERT in $14.2-\mathrm{cm}^{3}$ fixed-bed reactors at different superficial velocities $v$. The fixed beds consisted of $2 \mathrm{~mm}$ borosilicate glass spheres. The data represent the mean \pm SD of three cultivations in each case.

Figure 6: Experimental data of a hMSC-TERT cultivation in four parallel operated fixed-bed reactors with a volume of each $14.2 \mathrm{~cm}^{3}$. The reactors were connected to one conditioning vessel. Oxygen saturation was measured in the in and outlet of only one fixed-bed reactor. The data point of the counted cell number represents the mean \pm SD of the four reactors. The reactors were perfused with a superficial velocity $v$ of $2.7 \times 10^{-4} \mathrm{~m} \mathrm{~s}^{-1}$. The conditioning vessel contained $1000 \mathrm{ml} \mathrm{EMEM}+10 \%$ FCS.

Figure 7: Experimental data of a hMSC-TERT cultivation in a $60-\mathrm{cm}^{3}$ fixed-bed reactor. The reactors were perfused with a superficial velocity $v$ of $3.0 \times 10^{-4} \mathrm{~m} \mathrm{~s}^{-1}$. The conditioning vessel contained $500 \mathrm{ml} \mathrm{EMEM} \mathrm{+} \mathrm{10 \%} \mathrm{FCS.}$

Figure 8: Experimental data of a hMSC-TERT cultivation in a fixed-bed reactor with a volume of $300 \mathrm{~cm}^{3}$. The conditioning vessel contained $4800 \mathrm{ml}$ EMEM $+10 \% \mathrm{FCS}$. 
Figure 9: Yield and vitality of hMSC-TERT obtained with different harvesting procedures.

$\mathrm{n}$ : number of trials, $t_{e}$ : duration of perfusion with the enzyme solution, $t_{m}$ : duration of perfusion with the medium, $v_{e}$ : superficial velocity during incubation with the enzyme solution, $v_{m}$ : superficial velocity during the perfusion with medium

a) Accutase ${ }^{\mathrm{TM}} ; v_{e}=8.0 \times 10^{-4} \mathrm{~m} \mathrm{~s}^{-1} ; t_{e}=10 \mathrm{~min} ; \mathrm{n}=1$

b) Accutase ${ }^{\mathrm{TM}} ; v_{e}=1.6 \times 10^{-3} \mathrm{~m} \mathrm{~s}^{-1} ; t_{e}=10 \mathrm{~min} ; \mathrm{n}=1$

c) Accutase ${ }^{\mathrm{TM}} ; v_{e}=3.2 \times 10^{-3} \mathrm{~m} \mathrm{~s}^{-1} ; t_{e}=20 \mathrm{~min} ; \mathrm{n}=1$

d) Accutase ${ }^{\mathrm{TM}} ; v_{e}=1.8 \times 10^{-4} \mathrm{~m} \mathrm{~s}^{-1} ; v_{m}=1.6 \times 10^{-3} \mathrm{~m} \mathrm{~s}^{-1} ; t_{e}=10 \mathrm{~min}$; $t_{m}=1 \min ; \mathrm{n}=3$

e) Accutase ${ }^{\mathrm{TM}} ; v_{e}=1.8 \times 10^{-4} \mathrm{~m} \mathrm{~s}^{-1} ; v_{m}=1.6 \times 10^{-3} \mathrm{~m} \mathrm{~s}^{-1} ; t_{e}=10 \mathrm{~min}$; $t_{m}=2 \min ; \mathrm{n}=2$

f) Accutase ${ }^{\mathrm{TM}} ; v_{e}=1.8 \times 10^{-4} \mathrm{~m} \mathrm{~s}^{-1} ; v_{m}=3.2 \times 10^{-3} \mathrm{~m} \mathrm{~s}^{-1}, t_{e}=10 \mathrm{~min}$; $t_{m}=1 \mathrm{~min} ; \mathrm{n}=2$

g) Accutase ${ }^{\mathrm{TM}} ; v_{e}=1.8 \times 10^{-4} \mathrm{~m} \mathrm{~s}^{-1} ; v_{m}=3.2 \times 10^{-3} \mathrm{~m} \mathrm{~s}^{-1} ; t_{e}=10 \mathrm{~min}$; $t_{m}=2 \min ; \mathrm{n}=2$

h) Accutase ${ }^{\mathrm{TM}} /$ trypsin; $v_{e}=1.8 \times 10^{-4} \mathrm{~m} \mathrm{~s}^{-1} ; v_{m}=1.6 \times 10^{-3} \mathrm{~m} \mathrm{~s}^{-1} ; t_{e}=10$ $\min ; t_{m}=2 \min ; \mathrm{n}=2$ 
i) Accutase ${ }^{\mathrm{TM}} /$ trypsin; $v_{e}=1.8 \times 10^{-4} \mathrm{~m} \mathrm{~s}^{-1} ; v_{m}=3.2 \times 10^{-3} \mathrm{~m} \mathrm{~s}^{-1} ; t_{e}=10$ $\min ; t_{m}=2 \min ; \mathrm{n}=3$ 


\section{Tables}

Table 1: Performed hMSC-TERT cultivations in fixed-bed bioreactors at different scales. Bold-faced cultivations were used for the model verification in part B of this study.

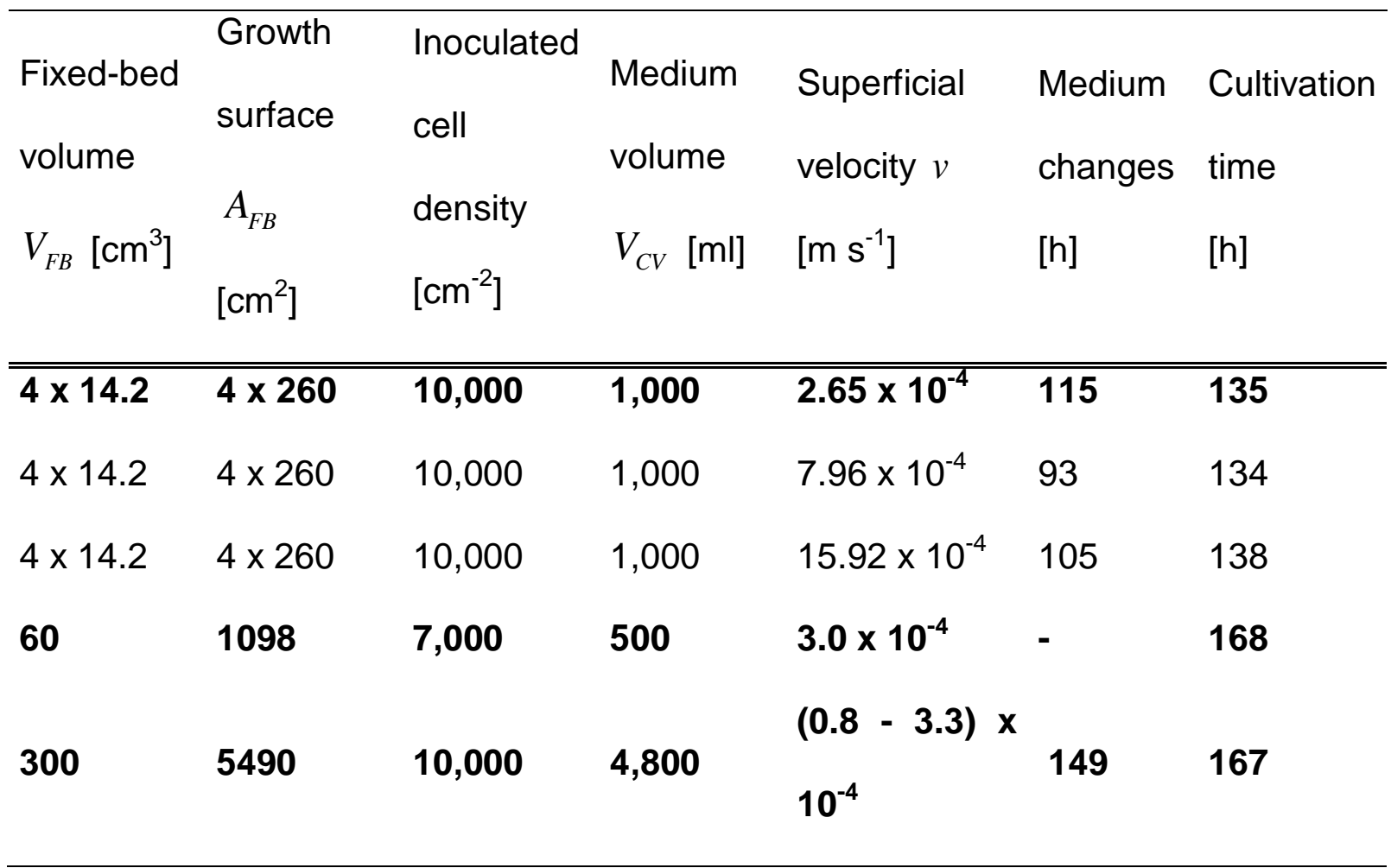


Table 2: Overview of the harvesting experiments performed in fixed-bed reactors at a scale of $14.2 \mathrm{~cm}^{3}$. A: Accutase ${ }^{\mathrm{TM}}$ solution, $\mathrm{T}$ : trypsin solution $(0.25 \%$ in PBS without calcium and magnesium)

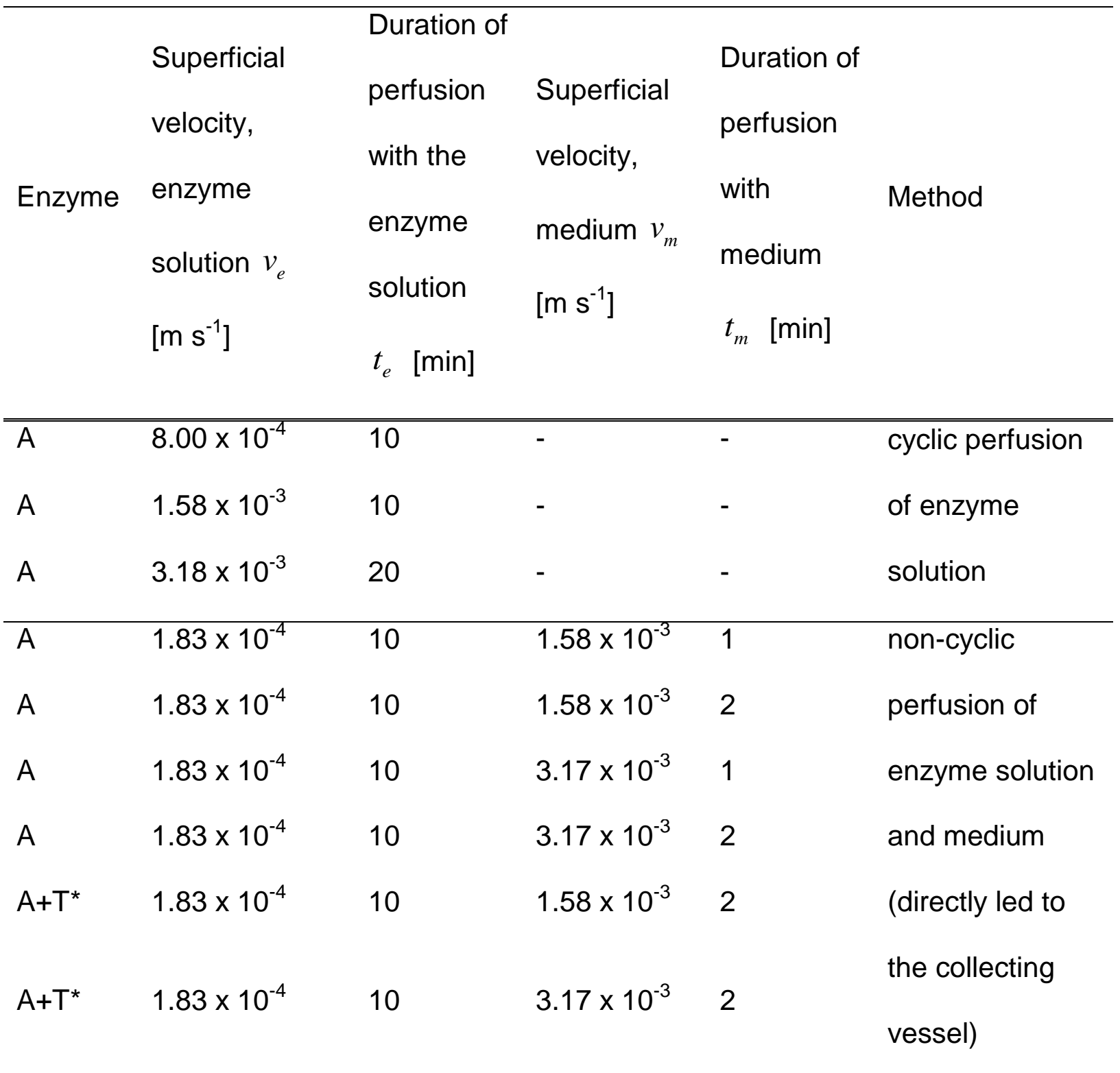


Table 3: Published growth kinetics of several cell types.

\begin{tabular}{|c|c|c|c|}
\hline \multirow[b]{2}{*}{ Cell type } & \multirow[b]{2}{*}{ Growth rate $\left[\mathrm{d}^{-1}\right]$} & \multirow{2}{*}{$\begin{array}{l}\text { Monod } \\
\text { constant } \\
{\left[\mathrm{mg} \mathrm{ml}^{-1}\right]}\end{array}$} & \multirow[b]{2}{*}{ Reference } \\
\hline & & & \\
\hline Adipose stem cells (rhesus & 0.37 (passage 11) & - & [24] \\
\hline monkey) & 0.23 (passage 14) & & \\
\hline Mesenchymal stem cells (human) & $0.66-0.94$ & - & [28] \\
\hline Mesenchymal stem cells (human) & 0.5 & - & [29] \\
\hline Mesenchymal stem cells (human) & 0.55 & - & [30] \\
\hline $\begin{array}{l}\text { Myeloma cell line X63-Ag8.653 } \\
\text { (murine) }\end{array}$ & 1.56 & 0.13 & [31] \\
\hline $\begin{array}{l}\text { Mesodermal progenitor cells } \\
\text { (human) }\end{array}$ & $0.33-1.3$ & - & [32] \\
\hline $\begin{array}{l}\text { Embryoicl stem cell line H9 } \\
\text { (human) }\end{array}$ & 0.47 & - & [33] \\
\hline
\end{tabular}


Table 4: Published glucose consumption kinetics of several cell types.

\begin{tabular}{|c|c|c|c|}
\hline Cell type & $\begin{array}{l}\text { Glucose consumption } \\
\text { rate }\left[\mathrm{mg}^{-1} \mathrm{~h}^{-1} \text { cell }^{-1}\right]\end{array}$ & $\begin{array}{l}\text { Monod } \\
\text { constant } \\
{\left[\mathrm{mg} \mathrm{ml}^{-1}\right]}\end{array}$ & $\begin{array}{l}\text { Referen } \\
\text { ce }\end{array}$ \\
\hline $\begin{array}{l}\text { Embryonic stem cell line S25 } \\
\text { (murine) }\end{array}$ & $(0.9-1.88) \times 10^{-8}$ & - & [7] \\
\hline Mesenchymal stem cells (human) & $(2.25-6.9) \times 10^{-8}$ & - & [28] \\
\hline $\mathrm{CHO}$ (hamster) & $8.46 \times 10^{-8}$ & - & [34] \\
\hline $\begin{array}{l}\text { Hybridoma cell line 4C10B6 } \\
\text { (murine) }\end{array}$ & $(0.13-1.37) \times 10^{-7}$ & - & [35] \\
\hline Mesenchymal stem cells (human) & $1.22 \times 10^{-7}$ & - & [36] \\
\hline Leucemic cell line K562 (human) & $1.59 \times 10^{-7}$ & - & [37] \\
\hline Vero (Chlorocebus) & $2.4 \times 10^{-8}$ & 0.1 & [38] \\
\hline
\end{tabular}


Table 5: Results of the hMSC-TERT cultivation in 2-mm borosilicate glass spheres comprising fixed-bed reactors.

\begin{tabular}{|c|c|c|c|c|}
\hline & Units & $V_{F B}=4 \times 14.2 \mathrm{~cm}^{3}$ & $V_{F B}=60 \mathrm{~cm}^{3}$ & $V_{F B}=300 \mathrm{~cm}^{3}$ \\
\hline Cultivation time & [h] & 135 & 168 & 167,3 \\
\hline Superficial velocity $v$ & {$\left[\mathrm{~m} \mathrm{~s}^{-1}\right]$} & $2.7 \times 10^{-4}$ & $3.0 \times 10^{-4}$ & $(0.8-3.3) \times 10^{-4}$ \\
\hline Lactate/glucose & $\begin{array}{l}{[\mathrm{mg} / \mathrm{mg}]} \\
{[\mathrm{mol} / \mathrm{mol}]}\end{array}$ & $\begin{array}{l}1.61 \\
3.22\end{array}$ & $\begin{array}{l}0.80 \\
1.60\end{array}$ & $\begin{array}{l}0.93 \\
1.86\end{array}$ \\
\hline Mean growth rate ${ }^{*} \mu_{\mathrm{m}}$ & {$\left[d^{-1}\right]$} & $0.60 \pm 0.02$ & $0.49 \pm 0.04$ & $0.42 \pm 0.02$ \\
\hline Mean glucose consumption rate ${ }^{*} q_{G l c, \mathrm{~m}}$ & {$\left[\mathrm{mg} \mathrm{h}^{-1}\right.$ cell $\left.^{-1}\right]$} & $(7.65 \pm 0.3) \times 10^{-8}$ & $(6.80 \pm 0.43) \times 10^{-8}$ & $(9.50 \pm 0.27) \times 10^{-8}$ \\
\hline * Correlation coefficient & {$[-]$} & 0.999 & 0.998 & 0.924 \\
\hline
\end{tabular}


Table 6: Published oxygen consumption kinetics of several cell types.

\begin{tabular}{|c|c|c|c|}
\hline Cell type & $\begin{array}{l}\text { Oxygen consumption } \\
\text { rate }\left[\mathrm{mg} \mathrm{h}^{-1} \text { cell }^{-1}\right]\end{array}$ & $\begin{array}{l}\text { Monod constant } \\
{[\mathrm{mg} \mathrm{ml}]}\end{array}$ & Reference \\
\hline $\begin{array}{l}\text { Adherent mononuclear cells } \\
\text { from bone marrow (human) }\end{array}$ & $(1.22 \pm 0,19) \times 10^{-8}$ & - & [39] \\
\hline Skin fibroblasts (rat) & $1.88 \times 10^{-8}$ & $2.0 \times 10^{-4}$ & [40] \\
\hline $\begin{array}{l}\text { Hematopoietic stem cells } \\
\text { (human) }\end{array}$ & $1.92 \times 10^{-8}$ & - & [41] \\
\hline $\begin{array}{l}\text { Breast cancer stem cells } \\
\text { (human) }\end{array}$ & $(3.2 \pm 0,07) \times 10^{-8}$ & $(2.3 \pm 0.5) \times 10^{-3}$ & [42] \\
\hline $\begin{array}{l}\text { Hybridoma cell line } 4 \mathrm{H} 11 \\
\text { (murine-human) }\end{array}$ & $1.1 \times 10^{-8}$ & - & [43] \\
\hline
\end{tabular}


Figures
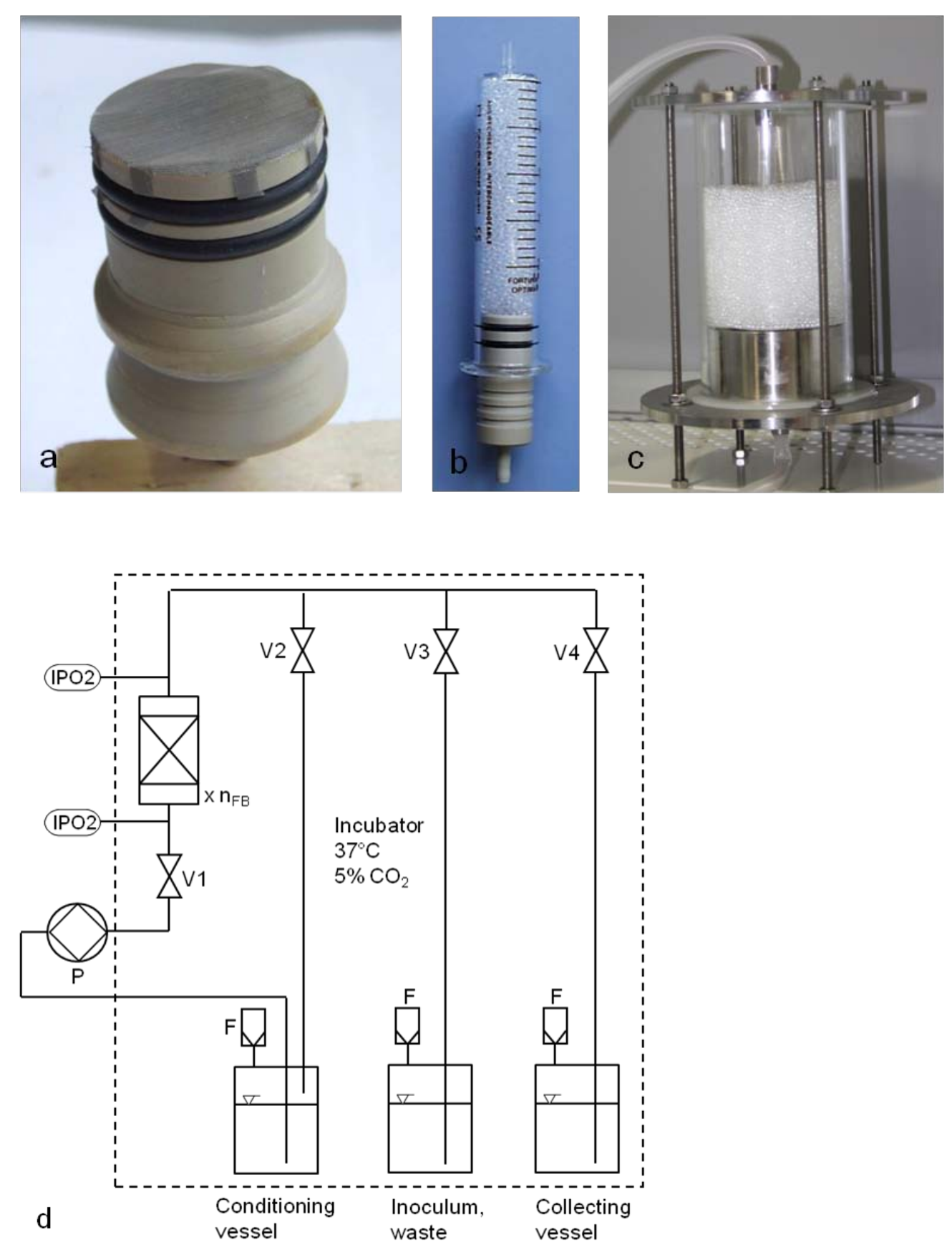

Figure 1 


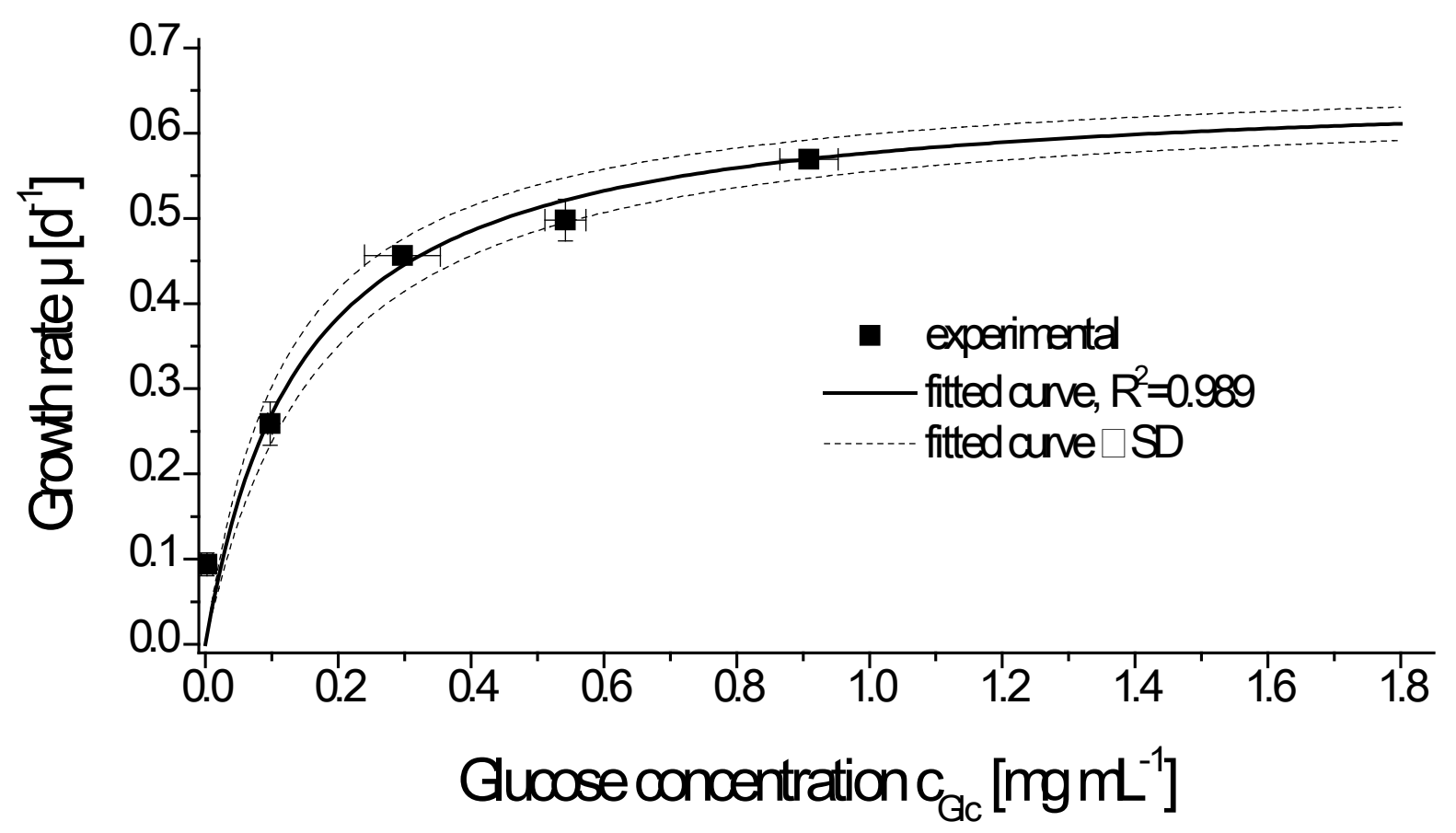

Figure 2 


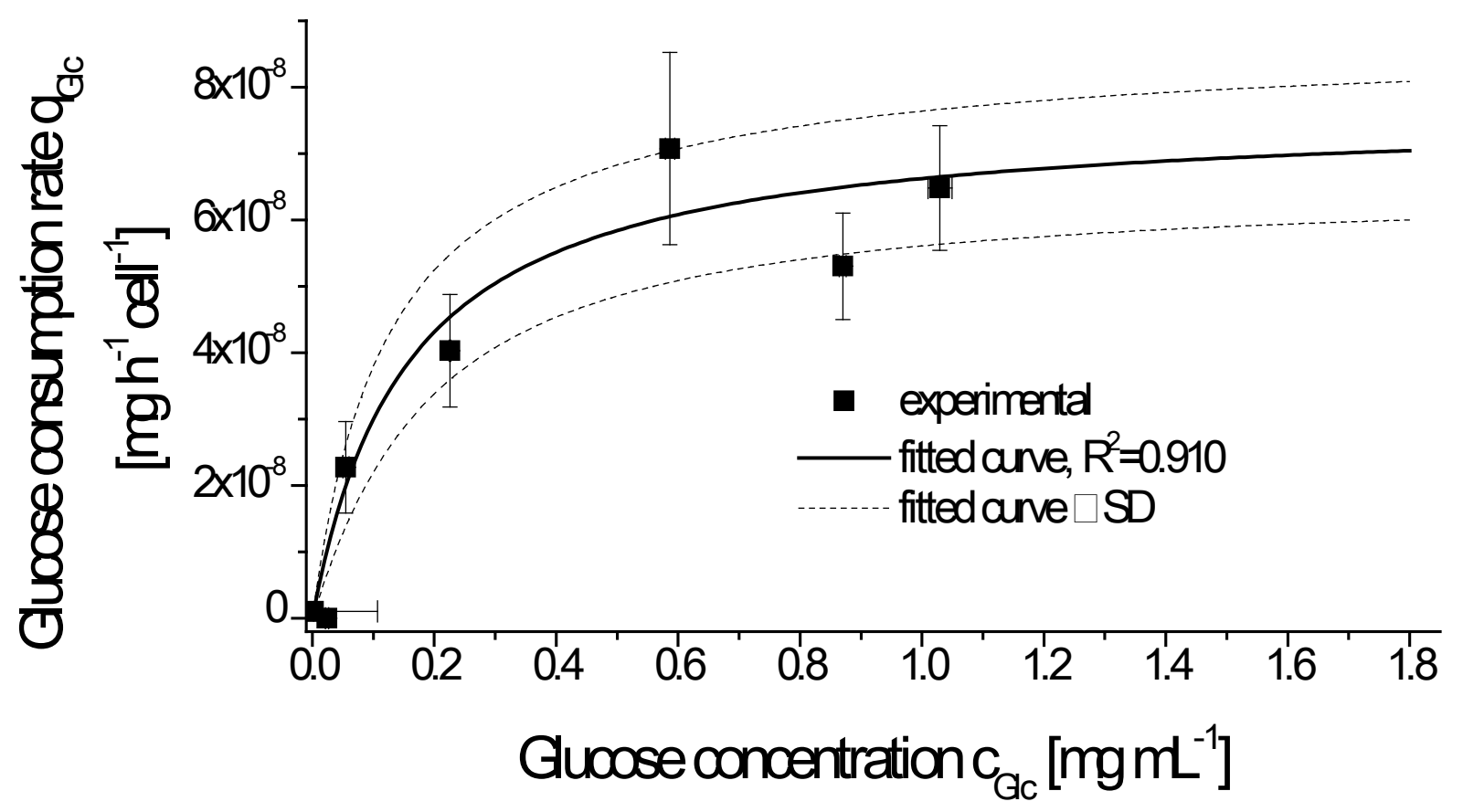

Figure 3 


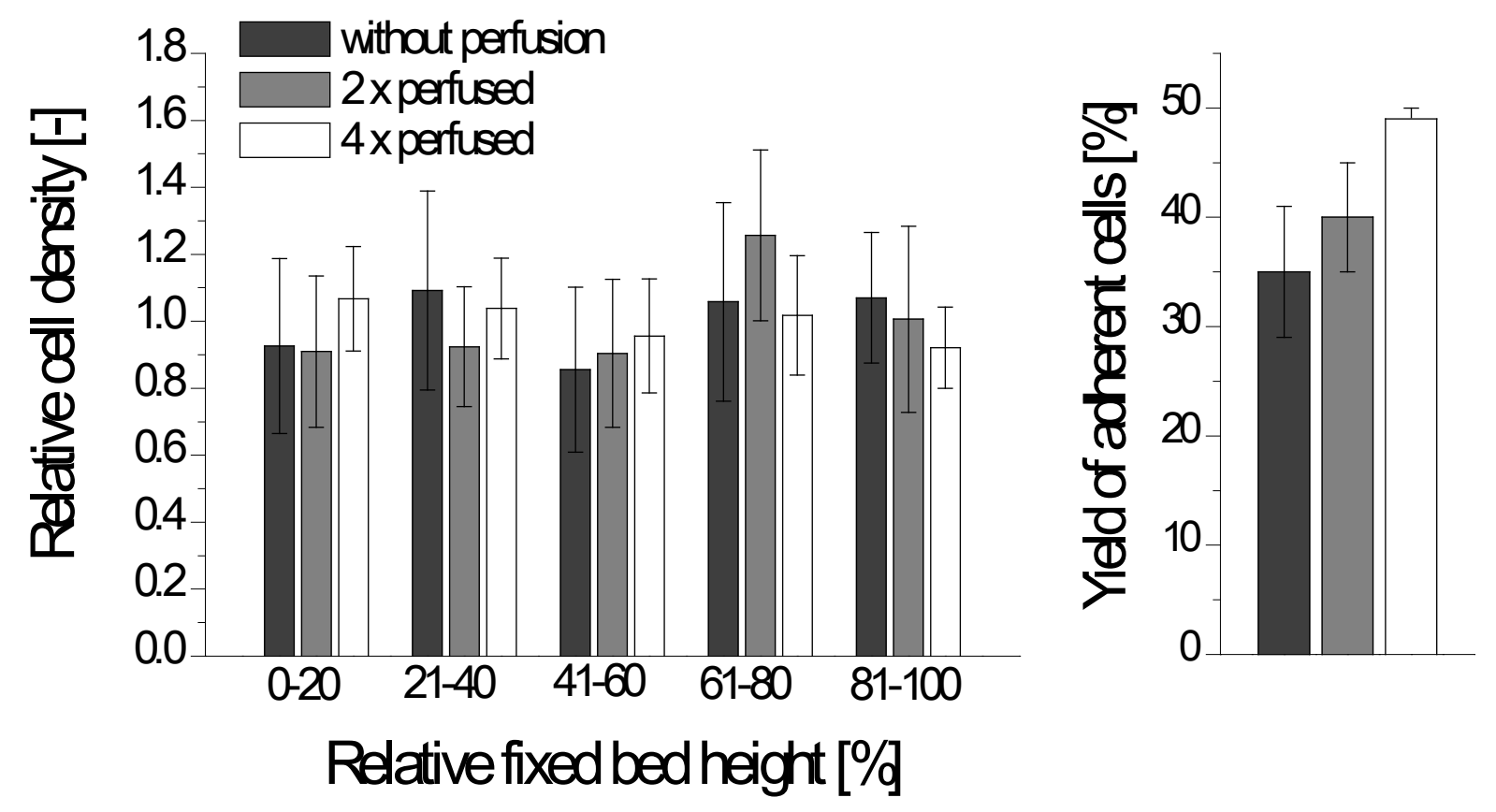

Figure 4 


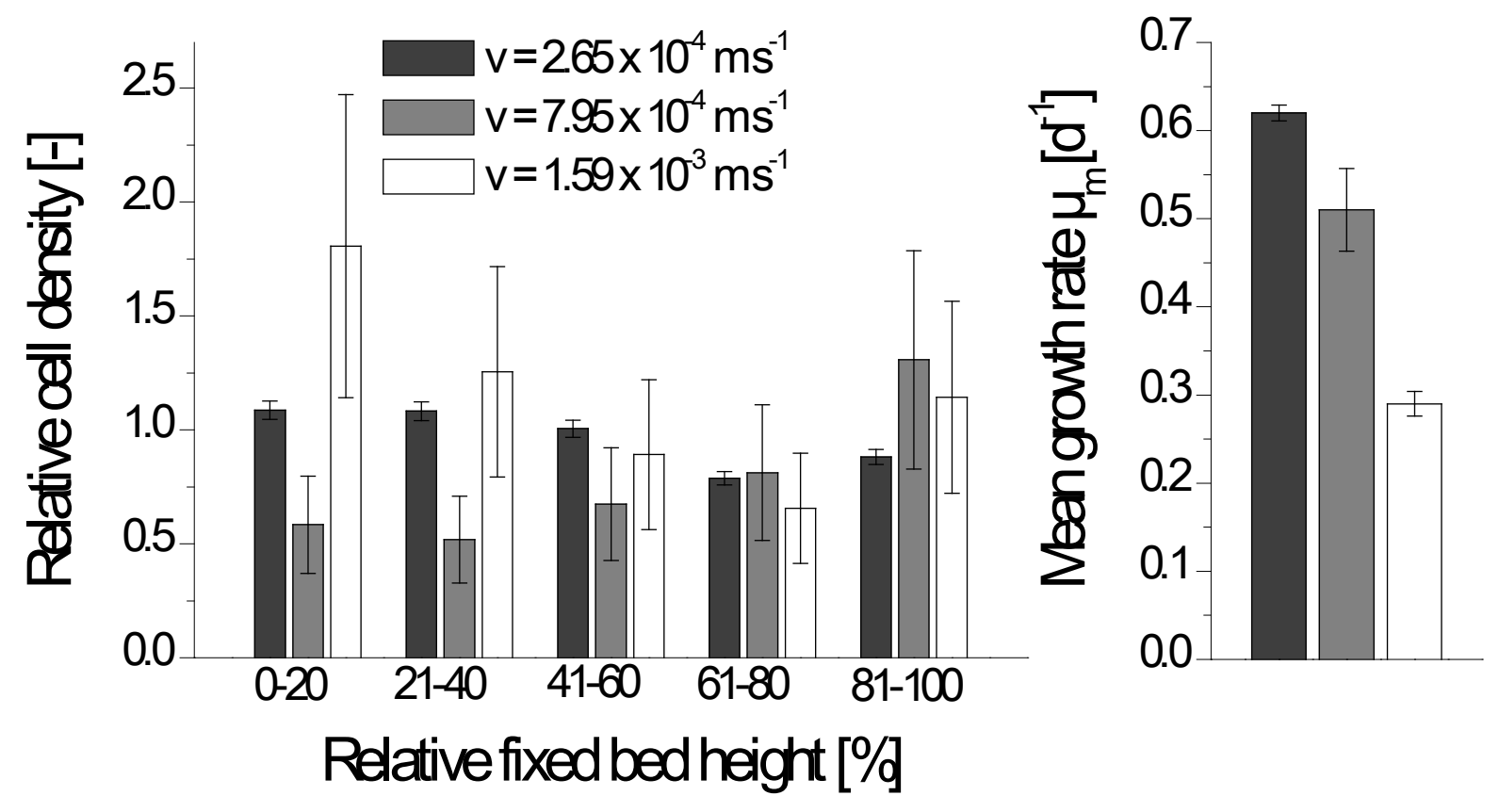

Figure 5 


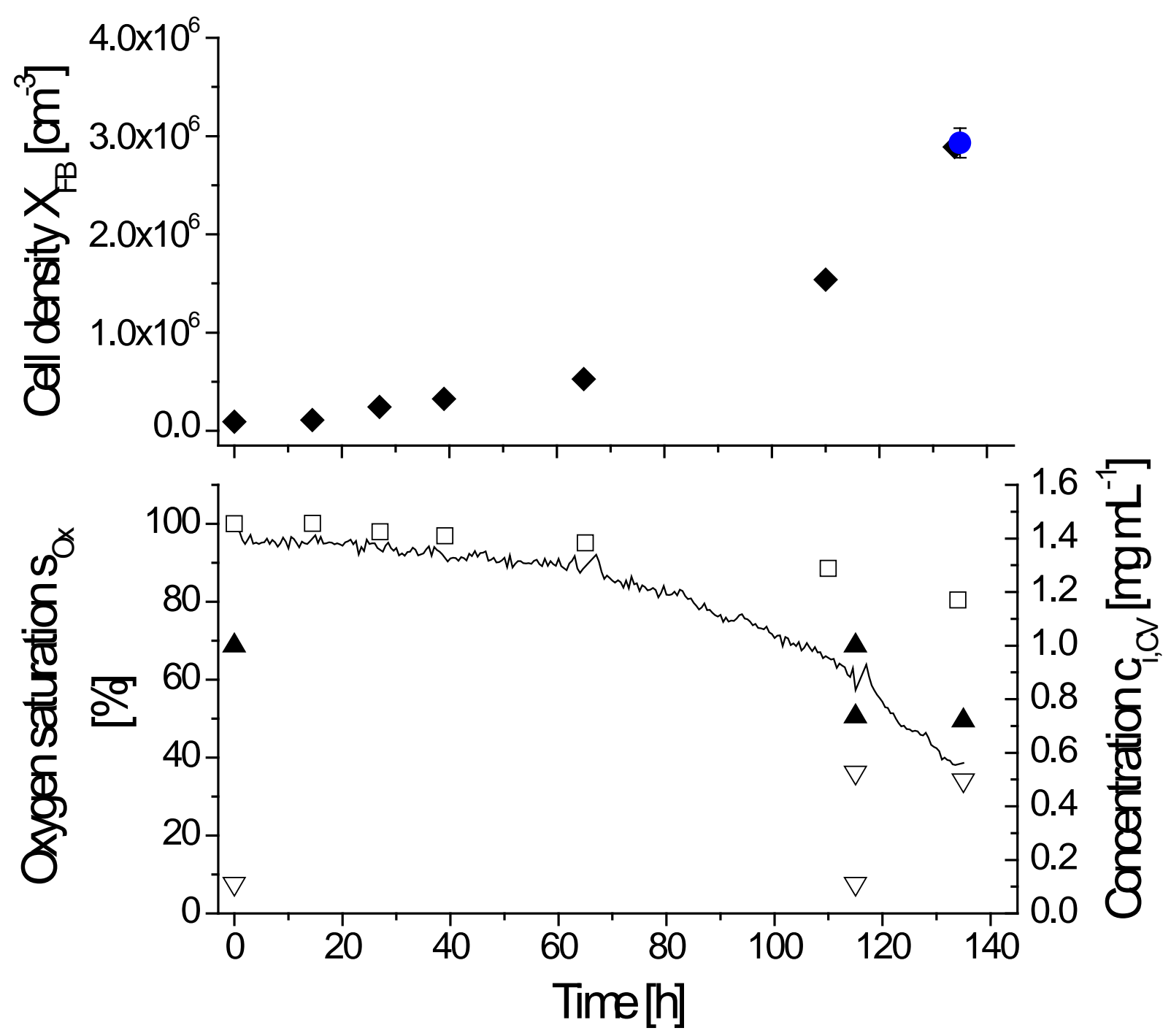

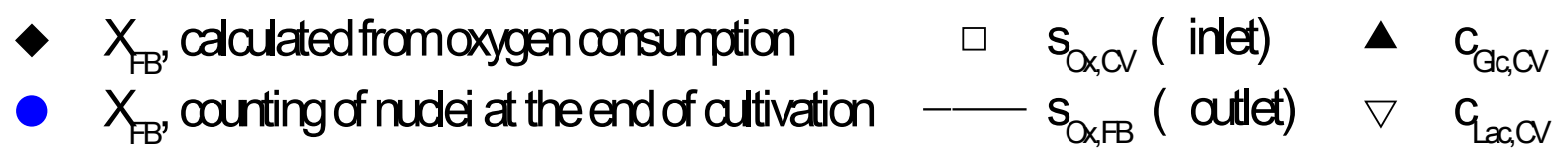

Figure 6 


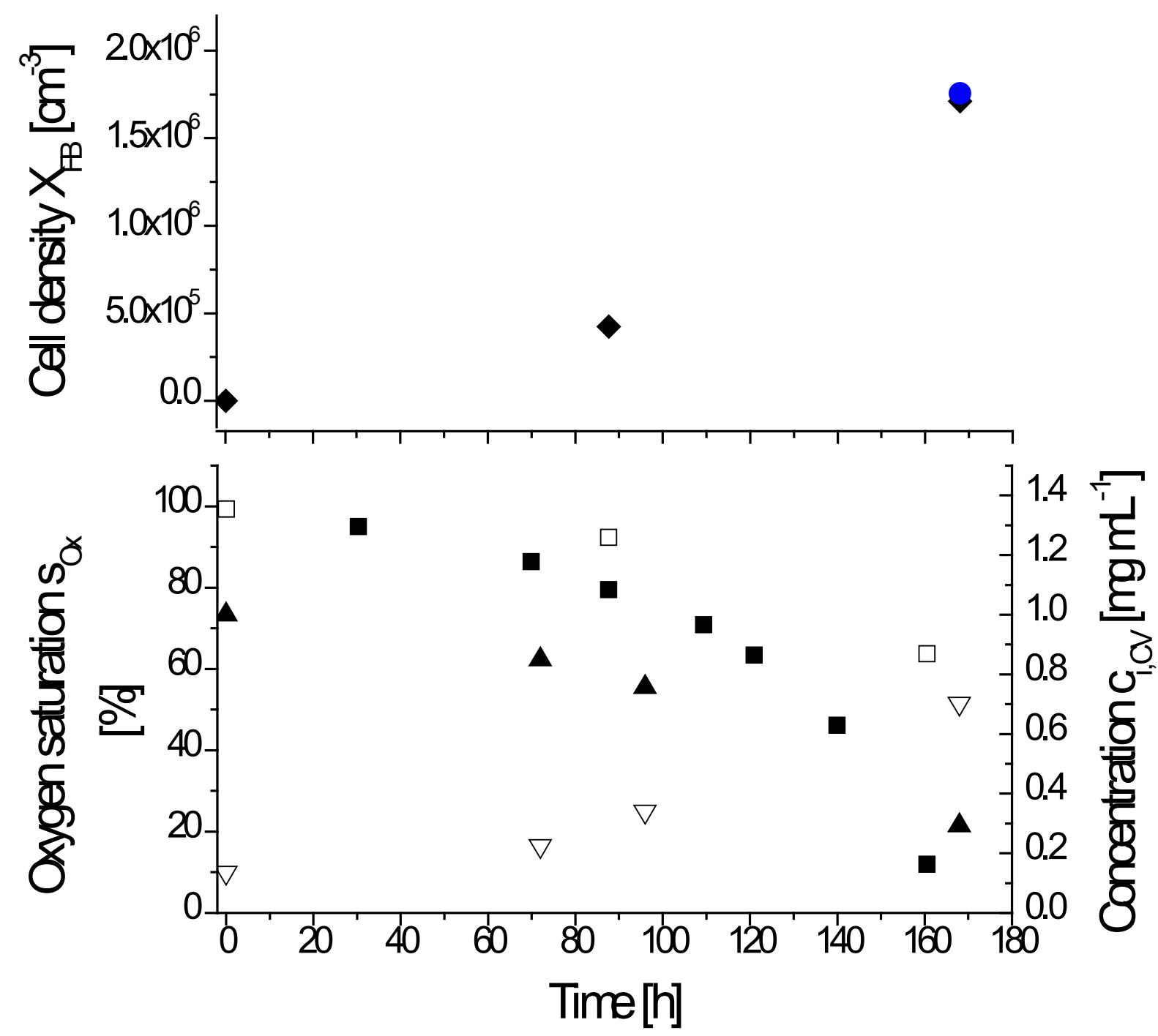

- $\mathrm{X}_{\mathrm{B}^{\prime}}$ calculated fromoxygen consumption $\quad \square \mathrm{s}_{\mathrm{OK}, \mathrm{V}}$ (inlet) $\quad \boldsymbol{\Delta} \mathrm{C}_{\mathrm{Gc}, \mathrm{OV}}$

- $X_{B^{\prime}}$, cunting of nudei at the end of altivation - $s_{\mathrm{OK}, \mathrm{B}}$ ( outlet) $\nabla \mathrm{G}_{x_{\mathrm{c}, \mathrm{V}}}$

Figure 7 


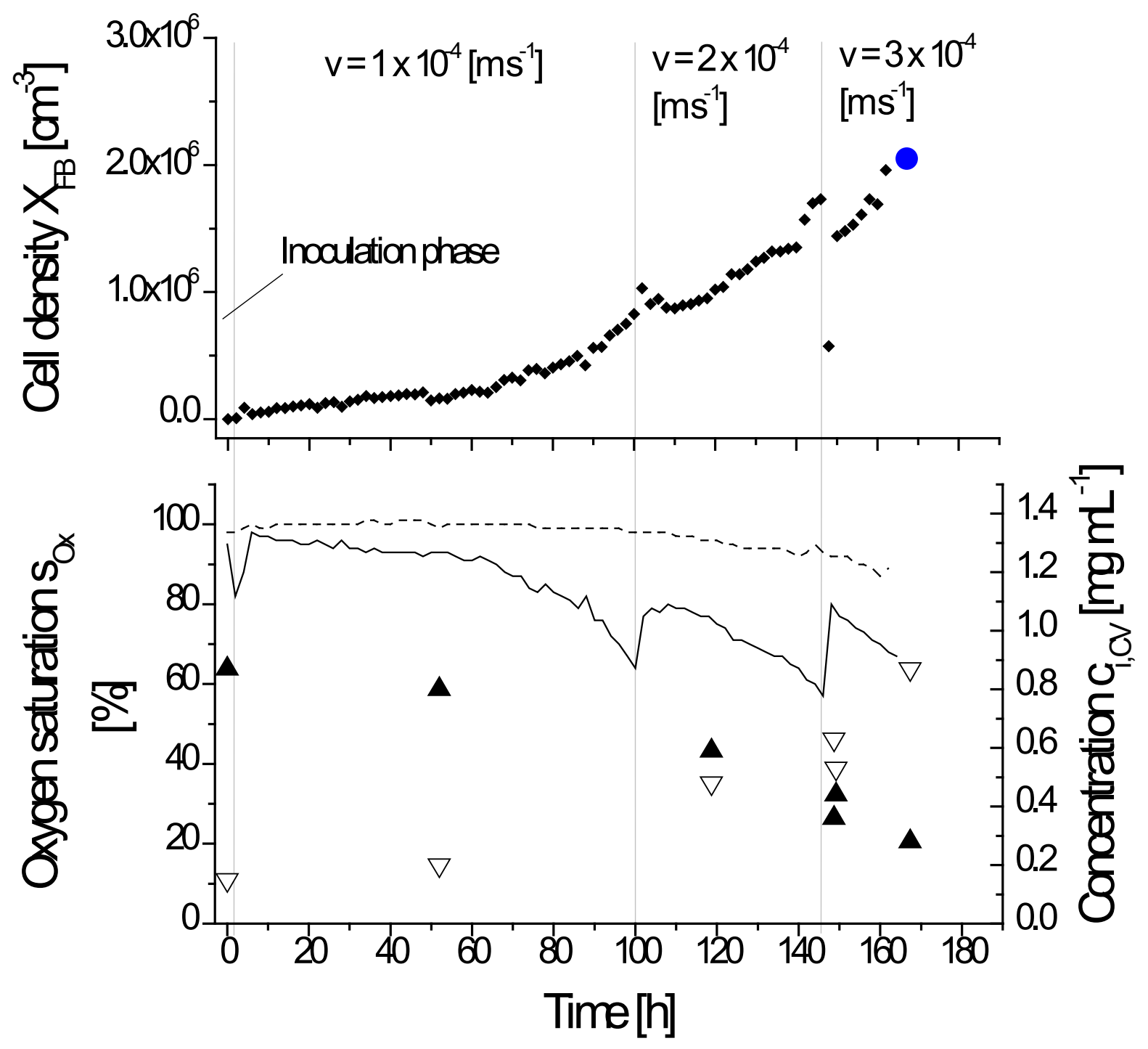

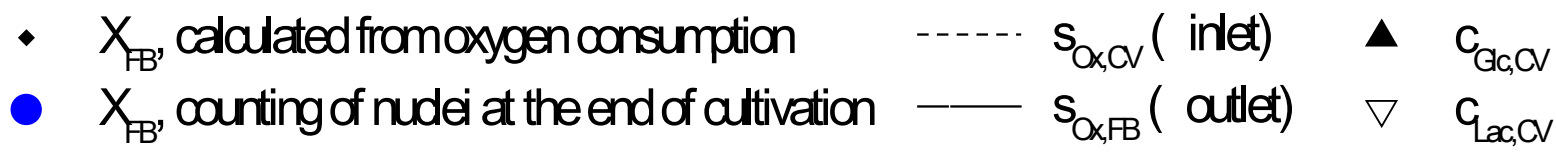

Figure 8 

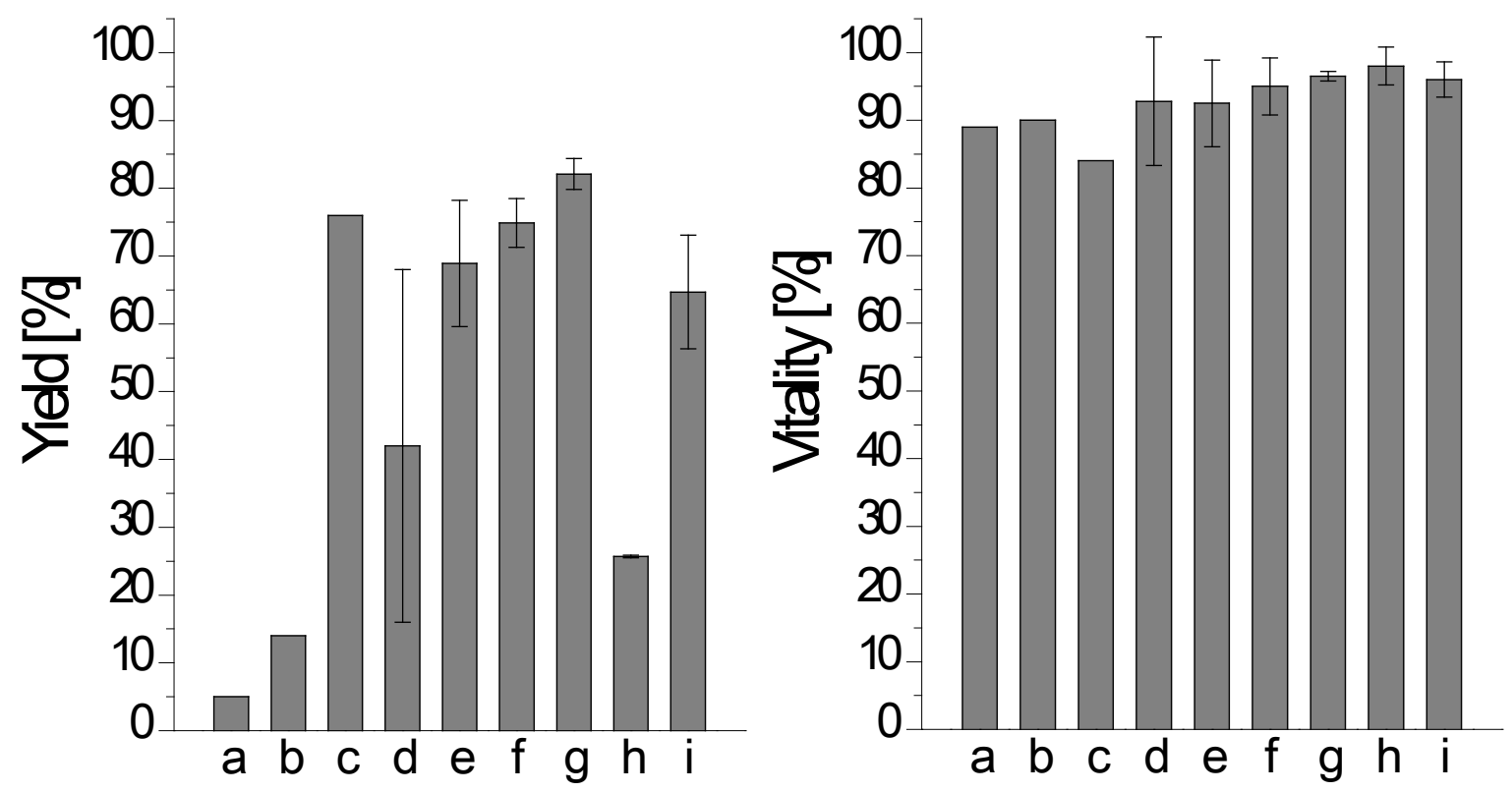

Figure 9 
